\title{
AS CIÊNCIAS COGNITIVAS
}

\author{
Milton José Penchel Madeira* \\ José Carlos Bins Filho*
}

SINTESE - O presente manifesto pretende apresentar à comunidade cientifica da PUCRS uma visão geral sobre as Ciências Cognitivas e a importância destas dentro das ciências atuais. Aborda brevemente 0 histórico das Ciências Cognitivas, especificando os diversos campos do conhecimento abrangidos pelo paradigma ou por suas metodologias e técnicas.
ABSTRACT - The purpose of this article is to show to scientific community of PUCRS a general view about the Cognitive Science and it's relevance within the context of contemporary science. It is presented a brief history about Cognitive Science and it's specific knowledge's domains supported by its paradigm as well as its methodologies and techniques.

Tem-se como certo que o papel das Ciências Cognitivas não pode ser mais negado ou desconsiderado no mejo acadêmico universitário. Seja desde o cientista que trabalha debruçado sobre a Bioquimica e/ou estrutura do cérebro, seja até aquele que questiona a natureza dos processos complexos que o psiquismo elabora para o gerenciamento do comportamento e sua possivel modelização ou simulação computacional; todos encontram-se numa instigante e, ao nosso ver, fascinante atividade de construção de saber.

As Ciências Cognitivas nasceram no final da década de 50 , a partir da reunião de diversos trabalhos de pesquisadores de diferentes áreas do conhecimento, mas que tinham um objetivo comum de instituir um campo de conhecimento voltado ao estudo dos processos mentais superiores. Entre estas áreas pode-se citar a Inteligência Artificial, a Teoria do Conhecimento. a Psicologia Cognitiva, a Lingüística Cognitiva, a Ergonomia Cognitiva, a Robótica e a Neurociência.

O objeto de estudo constituiu-se no estudo das cognições, como os processos de inteligência (tanto sob o ponto de vista psicológico propriamente dito quanto no de simulação computacional), raciocínio, pensamento, resolução de problemas, criatividade e outros. Não mais meramente no sentido do estudo da estrutura destes processos, mas, fundamentalmente, a nível dos processos que dizem respeito de maneira direta ou indireta acerca do fenômeno de organização do conhecimento, seja através de arquiteturas naturais ou artificiais.

Um dos trabalhos mais proeminentes desenvolvidos em Ciências Cognitivas está voltado ao uso de modelos computacionais capazes de simular comportamentos inteligentes, posto a Inteligência Artificial ter se constituído, num primeiro mo-

* Professores pesquisadores do Grupo de Discussão em Ciências Cognitivas da PUCRS.

\begin{tabular}{|l|l|l|l|l|l|}
\hline VERITAS & Por to Alegre & v. 40 & $\mathrm{n}^{\circ} 158$ & Junho 1995 & p. 233-234 \\
\hline
\end{tabular}


mento, como a disciplina central dentro das Ciências Cognitivas. Daí a metáfora que se tornou famosa dentro deste cabedal de conhecimentos de comparar a estrutura do psiquismo ou a mente humana a um computador: o cérebro seria o hardware e os processos mentais superiores que gerenciam o comportamento seriam os softwares.

Pode-se perceber que as Ciências Cognitivas possuem um caráter eminentemente multidisciplinar, onde os diversos campos de conhecimento interagem na busca da formação de uma teoria unificada da cognição, orientados pelo paradigma geral da explicação e predição dos processos cognitivos. Este esforço conjunto já gerou e continua gerando frutos importantes tanto a nivel aplicado como, por exemplo, os Tutores Inteligentes e, a nivel teórico, como a atual Teoria da Mente.

No que tange ao método, os cientistas na área, de maneira muito freqüente, utilizam o Método dos Modelos Axiomatizados Matematicamente e/ou o Método da Simulação Computacional. Tais métodos imprimem um forte caráter de cientificidade e respeitabilidade às Ciências Cognitivas por duas razões principais: 1) serem métodos respeitados e valorizados pela comunidade científica contemporânea, incluindo ai, portanto, os cientistas das Ciências Exatas; 2) buscarem a matematização e a implementação computacional dos conhecimentos produzidos.

A força do saber oriundo das Ciências Cognitivas mostra-se em expansão, tornando-se como um paradigma alternativo e/ou como técnica na área de aplicação de outras disciplinas. A nível dos campos do saber que utilizam os pressupostos das Ciências Cognitivas como paradigma alternativo, salientam-se a Educação e a Economia. A nível de aplicação técnica e/ou clínica podem se citar a Física e a própria Medicina.

Deste modo, os conhecimentos produzidos abrangem amplo espectro do saber e sua importância dentro das ciências tornou-se inegável. Veja-se, como prova, que há, atualmente, praticamente em todas as grandes universidades do mundo, centros de pesquisa em Ciências Cognitivas. 